\title{
POWERS OF TRADE UNION ACTIVISTS ENGAGED IN SELF-EMPLOYMENT - ASSESSMENT OF POLISH LEGISLATION ${ }^{1}$
}

\begin{abstract}
The objective of the foregoing article is an analysis of the rights which the Polish legislature granted to self-employed trade union activists after the extension of coalition rights to these persons. In this regard, the trade union law extended to self-employed persons working as sole traders protection, which until 2019 was reserved exclusively for employees. Pursuant to the amendment of July 5, 2018, self-employed trade union activists were granted - based on international standards - the right to non-discrimination on the basis of performing a trade union function, the right to paid leaves from work, both permanent and ad hoc in order to carry out ongoing activities resulting from the exercise of a trade union function, and the protection of the sustainability of civil law contracts which form the legal basis for the services provided. the exercise of a trade union function, and the protection of the sustainability of civil law contracts which form the legal basis for the services provided.

The author positively assesses the very tendency to extend employee rights to self-employed persons acting as union activists. However, serious doubts are raised by the scope of privileges guaranteed to non-employee trade union activists and the lack of any criteria differentiating this protection. Following the amendment of the trade union law, the legislator practically equates the scope of rights of self-employed trade union activists with the situation of trade union activists with employee status. This is not the right direction. This regulation does not take into account the specificity of self-employed persons, who most often do not have such strong legal relationship with the employing entity as employees. The legislature does not sufficiently notice the distinctness resulting from civil law contracts, which form the basis for the provision of work by the selfemployed the separateness resulting from civil law contracts, which constitute the basis for the performance of work by the self-employed. According to the author, the scope of rights guaranteed de lege lata to self-employed union activists constitutes an excessive and unjustified interference with the fundamental principle of freedom of contract on the basis of civil law employment relations (Art. $353^{1}$ of the Civil Code). From the point of view of international standards, it would be enough to ensure the right of these persons to non-discrimination on the basis of performing a trade union function; the right to unpaid temporary leaves from work in order to perform current activities resulting from the performed trade union function; the right to high compensation in the event of termination of a civil law contract with a self-employed trade union activist in connection with the performance of his functions in trade union bodies and full jurisdiction of labour courts in cases arising from the application of trade union law provisions.

The disadvantage of the regulation at issue is also that Polish collective labour law does not in any way differentiate the scope of the rights and privileges guaranteed to self-employed trade union
\end{abstract}

*University of Lodz, Department of Labour Law; tduraj@wpia.uni.lodz.pl

${ }^{1}$ The article was prepared as part of a project financed by the National Science Centre in Poland pursuant to the decision number DEC-2018/29/B/HS5/02534. The project's registration number is: $2018 / 29 / \mathrm{B} / \mathrm{HS} 5 / 02534$. 
activists, ensuring the same level of protection for all. In that area, it appears that the legislature de lege ferenda should differentiate the scope of that protection by referring to the criterion of economic dependence on the hiring entity for which the services are provided.

Keywords: self-employment, trade union activists, right of coalition, self-employment, trade unions.

\section{UPRAWNIENIA DZIALACZY ZWIĄZKOWYCH WYKONUJĄCYCH PRACE ZAROBKOWĄ NA WLASNY RACHUNEK - OCENA POLSKIEJ REGULACJI PRAWNEJ}

Streszczenie. Przedmiotem artykułu jest analiza uprawnień, jakie polski ustawodawca zagwarantował samozatrudnionym działaczom związkowym po rozszerzeniu na te osoby prawa koalicji. W tym zakresie ustawa związkowa rozciągnęła na osoby pracujące zarobkowo na własny rachunek w ramach jednoosobowej działalności gospodarczej ochronę, która do 2019 roku była zastrzeżona wyłącznie dla pracowników. Na mocy nowelizacji z dnia 5 lipca 2018 roku przyznano samozatrudnionym działaczom związkowym - powołując się na standardy międzynarodowe - uprawnienia w przedmiocie niedyskryminacji ze względu na pełnienie funkcji związkowej, prawo do płatnych zwolnień od świadczenia pracy, zarówno o charakterze stałym, jak i doraźnym, w celu wykonywania bieżących czynności wynikających z realizowanej funkcji związkowej, a także ochronę trwałości kontraktów cywilnoprawnych stanowiących podstawę prawną świadczonych usług.

Autor pozytywnie ocenia samą tendencję co do rozszerzania uprawnień pracowniczych na osoby samozatrudnione pełniące funkcję działaczy związkowych. Poważne wątpliwości budzi jednak zakres przywilejów gwarantowanych związkowcom-niepracownikom oraz brak jakichkolwiek kryteriów różnicujących tę ochronę. Ustawodawca po nowelizacji prawa związkowego praktycznie zrównuje zakres uprawnień samozatrudnionych działaczy związkowych z sytuacją związkowców posiadających status pracowniczy. To nie jest właściwy kierunek. Regulacja ta nie uwzględnia w żadnym razie specyfiki osób pracujących na własny rachunek, które najczęściej nie pozostają $\mathrm{w}$ tak silnej więzi prawnej $\mathrm{z}$ podmiotem zatrudniającym, jak pracownicy. Ustawodawca nie dostrzega $\mathrm{w}$ wystarczającym stopniu odrębności wynikających $\mathrm{z}$ umów cywilnoprawnych, które stanowią podstawę świadczenia pracy przez samozatrudnionych. Zakres uprawnień gwarantowanych de lege lata samozatrudnionym działaczom związkowym zdaniem Autora stanowi nadmierną i nieuzasadnioną ingerencję $\mathrm{w}$ fundamentalną na gruncie cywilnoprawnych stosunków zatrudnienia zasadę wolności umów (art. $353^{1} \mathrm{KC}$ ). Z punktu widzenia standardów międzynarodowych wystarczyłoby zapewnić tym osobom prawo do niedyskryminacji ze względu na pełnienie funkcji związkowej; prawo do nieodpłatnych doraźnych zwolnień od świadczenia pracy w celu wykonywania bieżących czynności wynikających z realizowanej funkcji związkowej; prawo do wysokiej rekompensaty na wypadek rozwiązania z samozatrudnionym działaczem związkowym umowy cywilnoprawnej w związku z wykonywaniem przez niego funkcji w organach związku zawodowego oraz pełną kognicję sądów pracy w sprawach powstających na tle stosowania przepisów prawa związkowego.

Wadą analizowanej regulacji jest również to, że polskie zbiorowe prawo pracy nie różnicuje w żaden sposób zakresu uprawnień i przywilejów gwarantowanych samozatrudnionym działaczom związkowym, zapewniając wszystkim ten sam poziom ochrony. Wydaje się, że w tym obszarze ustawodawca de lege ferenda powinien zróżnicować zakres tej ochrony, odwołując się do kryterium zależności ekonomicznej od podmiotu zatrudniającego, na rzecz którego świadczone są usługi.

Słowa kluczowe: samozatrudnienie, działacze związkowi, prawo koalicji, praca na własny rachunek, związki zawodowe. 


\section{INTRODUCTORY NOTES}

Both in Polish legislation and in the regulations of many European countries, there has been a clear trend towards extending certain powers, until recently reserved exclusively to employees, to contractors of civil law contracts (Duraj 2018, 37 and the following). This group includes self-employed persons, by which I mean, for the purposes of this article, natural persons who personally provide services to one or more (multiple) contracting entities in the context of a sole economic activity as traders, under their own responsibility and risk, without being able to hire employees or use someone else's work under civil law contracts (Duraj 2009, 24 and the following). This trend is largely the result of adapting national legal systems to standards based on international and EU law standards, and in Poland also a consequence of adapting labour legislation to constitutional requirements. It is also the result of the spread of self-employment in the market economy, which is increasingly crowding out the classic employment relationship due to the possibility of significant reduction of employment costs (the selfemployed is the one who bears all the burdens and risks associated with the work provided, especially social risks) and the pursuit of a rational employment policy (the contracting entity can relatively easily opt out of the services of a self-employed person). According to BAEL, in Poland, in the first quarter of 2020 the number of working people amounted to 16.4 million, of which more than 2.33 million were self-employed (more than $14 \%)^{2}$ and this number is gradually increasing.

Until 2019, under Polish law, the self-employed could enjoy the rights of an individual nature only, especially in the field of life and health protection including the prohibition of discrimination and the requirement of equal treatment in employment; guaranteed minimum wage and protection of wages as well as protection of motherhood and parenthood (cf. Duraj 2019, 341 and the following). The turning point was 1 January 2019, when the law of 5 July 2018 amending the Trade Union Act and certain other laws (Journal of Acts 2018, item 1608) entered into force. According to the amendment, people who were personally engaged in gainful employment outside the employment relationship, and therefore also self-employed persons with a single-person economic activity, if they do not hire other persons for such work (services), were granted the right to form nonemployee trade union organisations and to join existing workers' unions on the same basis as regular employees. This is a fundamental qualitative change, since membership of trade union organisations paves the way for collective labour law powers immanently linked to the right of coalition, under which they have the right not to be discriminated against on the grounds of union membership or lack

${ }^{2}$ https://stat.gov.pl/download/gfx/portalinformacyjny/pl/defaultaktualnosci/5475/4/37/1/aktywnosc_ekonomiczna_ludnosci_polski_i_kwartal_2020_roku.zip. 
thereof; the right to bargain with a view to the conclusion of a collective labour agreement and other collective agreements; the right to bargain for the particular purpose of the resolution of collective disputes, as well as the right to organise strikes and other forms of protest within the limits laid down by the law. Furthermore, the right of coalition enables self-employed persons to be active in trade union structures, which gives them the power of non-discrimination for their participation in any trade union activities, the right to paid time off (permanent or ad hoc) for the performance of the day-to-day activities resulting from the trade union function, and the protection of the durability of civil law contracts which constitute the legal basis for the services provided. It is precisely this entitlement of self-employed trade union activists that will be analysed in the foregoing article. While the trend towards extending the collective rights to persons carrying out gainful employment as sole traders should be positively assessed, the scope and criteria of this protection and its regulation leaves much to be desired and may give rise to a number of interpretative doubts in practice.

\section{RATIO LEGIS OF THE PRIVILEGED POSITION OF TRADE UNION ACTIVISTS ENGAGED IN SELF-EMPLOYMENT}

Until the amendment of Trade Union Act, under Polish law trade union membership was reserved only to employees, i.e. natural persons employed on the basis of an employment relationship. The primary objective of granting special privileges and protection to trade union activists, is, first and foremost, to guarantee the independence of trade unions as a social partner who, by representing and defending the rights and interests of economic operators and controlling the employer's compliance with labour law, runs the risk of retaliation on his part (cf. Dral 1997/1998, 285 and the following). The union activists must enjoy statutory privileges in order to be able to properly and effectively act as employees" representatives without exposing themselves to the negative consequences of the actions taken by the hiring entity. Such justification for the special powers and privileges of trade union activists has a strong position in the norms of international law. First of all, attention should be paid to the provisions of The International Labour Organisation (ILO) Convention No 135 ratified by Poland of 23 June 1971 concerning the protection and facilitation of workers ${ }^{6}$ representatives in enterprises (Journal of Acts 1977, No. 39, item 178). In accordance with Article 1 thereof, trade union activists, as representatives of employees in an enterprise, should enjoy effective protection against any acts of harm, including dismissal, taken by reason of their nature or activity as employees" representatives, their trade union membership or participation in trade union activities, provided that they act in accordance with the legislation in force, collective agreements or other commonly agreed agreements. Detailed 
guarantees in this regard are set out in Article 6 of ILO Recommendation No. 143 supplementing that Convention, indicating also the need to specify the reasons for dismissal, the obligation to obtain the opinion or consent of the relevant body for such dismissal or the possibility of claiming reinstatement or compensation by an unlawfully dismissed trade union activist (Kurzynoga 2019, 1091 and the following). Importantly, according to the guidelines of the ILO Committee on Freedom of Association, these guarantees should not be limited to employees only, but should cover all employees and their representatives, regardless of the legal basis for the provision of work (Podgórska- Rakiel 2013, 72; PodgórskaRakiel 2014, 510-511). Similar provisions are included in the Revised European Social Charter of 3 May 1996, which Poland has not ratified to date. In accordance with point 28 of Part I of the Charter, workers' representatives in an enterprise have the right to protection against actions detrimental to them and should be provided with adequate facilities for the performance of their tasks. Article 28 of Part II of the Charter, on the other hand, contains more detailed obligations of the States - Parties to the Charter in this regard. In order to ensure the effective exercise of the right of employees' representatives to fulfil their duties, the Parties undertake to ensure that they enjoy effective protection against acts detrimental to them, including dismissals, which would be caused by their status or activities as employees" representatives in the enterprise, and shall be given adequate facilities to enable them to fulfil their duties quickly and effectively, taking into account the existing system of professional relations in the country, as well as the needs, size and capabilities of the enterprise concerned.

The legislature, introducing the amendment to the Trade Union Act of 5 July 2018, decided to broaden the scope of the right of the coalition to persons who personally perform gainful employment outside the employment relationship and, therefore, to grant self-employed persons who act as trade union activists a similar range of rights and privileges, ensuring that they effectively carry out the tasks of representation of the persons carrying out the work for the employment entity concerned. The explanatory memorandum to the draft amendment (8th term Parliament paper no. 1933) states that the primary objective of protecting a trade union activist is to guarantee his independence in the performance of his duties. There is therefore no basis for making that protection dependent on the existence of a certain type of legal link between the person engaged in gainful employment and the employer. Consequently, as a result of the extension of the law of the trade union coalition to new groups of entities, it was necessary to extend the aforementioned protection also to non-employee trade union activists within the meaning of the Labour Code (law of 26 June 1974, i.e. Journal of Acts of 2020, item 1320, as amended - hereinafter KP). Making this protection dependent on the type of legal link between a person engaged in gainful employment and an employer would lead to a diversity of legal guarantees for a certain category of people performing essentially the same social function and exposed to the same acts of retort or 
repression by the employer. ${ }^{3}$ Although I agree, in principle, with that argument, I am not convinced by the scope of that protection and of the privileges, which are practically the same as the ones granted to trade unionists having the status of employees. The legislature does not sufficiently notice the distinctness resulting from civil law contracts, which form the basis for the provision of work by the selfemployed (service contract, contract to perform a specified task). These persons are governed by a completely different legal regime, which is based on the provisions of the Civil Code (Law of 23 April 1964, i.e. Journal of Acts 2020, item 1740 as amended - hereinafter KC). Their legal situation is governed by standards of dispositive nature, which apply unless the parties decide otherwise in civil law context. ${ }^{4}$ This regime is therefore based on the principle of freedom of agreements (art. $353^{1} \mathrm{KC}$ ), where there is a far-reaching autonomy in shaping the relationship between the parties to the agreement. ${ }^{5}$ Guaranteeing pursuant to the provisions of the law of 23 May 1991 on trade unions (i.e. Journal of Acts 2019, item 263, as amended - hereinafter referred to as the Trade Union Act) self-employed union activists privilege and protection at a level almost identical to that of regular employees, constitutes excessive and unjustified interference with the fundamental principle of the freedom of employment under civil employment relations. This regulation also does not take into account the specificities of self-employed persons, who most often do not have such a strong legal relationship with the hiring entity as employees. ${ }^{6}$ It is also worth noting that, for years, labour law has criticised the excessive level of protection and privilege that the legislature guarantees Polish workers in union functions (see, for example, Sanetra 1993; Sobczyk 2017, 178). It goes well beyond international standards, as is best seen in the example of the special protection of the durability of the employment of trade union activists, as will be mentioned later in the article (see, more broadly, Kurzynoga 2020, 176 and the following).

A significant disadvantage of the amended Trade Union Act is also the inaccurate description of persons engaged in gainful employment outside the

${ }^{3}$ The draft authors thus justify extending the protection of the durability of employment to non-union workers. However, the same argument concerns other employee entitlements granted to trade union workers who provide gainful employment outside the employment relationship.

${ }^{4}$ On the other hand, the employment relationship is governed primarily by semi-imperative standards, which can be modified in favour of the parties only one way, in favour of the employee. Sometimes there are also ius cogens norms, from which no derogations can be made.

${ }^{5}$ This is not the case under labour law, where the employee privilege principle applies. In accordance with Article 18 of the Labour Code, the provisions of employment contracts must not be less favourable to the worker than the provisions of labour law. Provisions less favourable to the worker than labour law are invalid and the relevant labour law provisions apply instead.

${ }^{6}$ Civil law contracts linking the self-employed to the contracting entity are usually not very stable (either party can terminate the contract at any time), make the payment of remuneration dependent on the results of work, and the self-employed in many cases provide their services in parallel to several contractors. 
employment relationship included in $\operatorname{Article1}^{1}(1)$. This results in a not fully defined personal scope of right of coalition and, importantly for the subject under question, raises problems in clarifying which persons specifically can perform functions in trade union organisations. According to the abovementioned provision, those persons include, in addition to employees, persons who provide paid work on a basis other than an employment relationship if they do not employ other persons for that type of work, irrespective of the basis of employment, and have rights and interests relating to the performance of work which may be represented and defended by the trade union. In particular, the reservations concern the condition of rights and interests. The doctrine of labour law (see, for example, Stelina 2018, 26) raises the difficult verifiability of this criterion, given that everyone who provides work (services) most often has some interest in the economic conditions of the performance of work (living or social). It is therefore easy to circumvent that condition by skillfully defining in the statutes the objectives and tasks of the trade union concerned. De lege lata there are also no instruments to effectively verify whether a group of entities forming a trade union organisation has rights and interests related to the performance of work that can be represented and defended by a trade union. There is also no entity that can verify this. Neither the hiring entity with which the trade union is formed nor the court at the registration stage of the trade union have such opportunities. However, there is no doubt that right of coalition, and thus the status of trade union activist, can only be exercised by those persons who work for profit outside the employment relationship, who have an employment entity for which they provide certain services and for whom their rights and interests can be collectively represented. As regards the self-employed, they generally have professional, economic and social interests relating to the services provided in the course of their economic activity, which must be protected in groups with the active support of trade unions. Trade union membership has the opportunity to improve their legal situation by introducing minimum protection measures which they do not enjoy by law alone. However, if the consolidation of the self-employed were merely to protect the economic, tax, or copyright interests of the sole traders associated there, this is not the basis for the exercise of the coalition right and thus for being a trade union activist (see, more broadly, Duraj 2020, 67 and the following).

\section{RIGHT TO EQUAL TREATMENT IN THE EXERCISE OF A TRADE UNION FUNCTION}

The first right guaranteed by the legislature to self-employed persons exercising the function of trade union activists is the right to equal treatment. In accordance with Article 3(1) of the Trade Union Act, any unequal treatment of the self-employed persons for their participation in union activities resulting 
in particular in the refusal to establish or terminate a legal relationship, the unfavourable formation of remuneration for gainful employment or other conditions of employment, being overlooked for a promotion, being refused other benefits relating to gainful employment, as well as being overlooked for any professional development training, shall be prohibited, unless the hiring entity proves that it was guided by objective reasons. The above list of the different behaviours which may be characteristic for unequal treatment in employment due to the performance of the trade union functions is not complete and serves only as an example. Moreover, following the example of the mechanism used in the employment relationship (Article 18(3) of the KP), the legislature interferes with the content of civil law contracts by providing for additional protection against discrimination. The provisions of the contracts under which self-employed persons carry out work infringing the principle of equal treatment in employment for their participation in union activities and exercising of a trade union function are invalid. Instead of such provisions, the relevant legal provisions governing the legal relationship between those persons and the employer shall apply and, in the absence of such provisions, they shall be replaced by appropriate nondiscriminatory provisions (Article 3(4) of the Trade Union Act).

In addition, in order to strengthen the protection of self-employed trade union activists, the legislature, in respect of claims for breach of the prohibition on unequal treatment in employment on account of the exercise of their trade union functions, requires that the provisions of Article $18^{3 \mathrm{~d}}$ and Article $18^{3 \mathrm{e}}$ of the $\mathrm{KP}$ on workers be applied accordingly. This means that the self-employed in such a situation will be entitled to compensation of not less than the minimum wage. Since self-employment is most often based on a service contracts and contracts to perform a specified task, which are characterised by a variable and irregular amount of remuneration, it must be assumed that this is the minimum amount of remuneration guaranteed in the full-time employment (similarly Grzebyk, Pisarczyk 2019, 87-88). Furthermore, the exercise by a self-employed trade union activist of the rights enjoyed for breach of the principle of equal treatment in employment cannot be the basis for his unfavourable treatment and must not have any negative consequences for him, in particular, it cannot give rise to a reason justifying the termination of his civil law contract. Persons who have provided assistance to the self-employed in any form of redress are also protected in the same way. It is to be welcomed that the legislature, in cases concerning infringement of the prohibition of unequal treatment in employment on account of the exercise of a trade union function, expressis verbis requires that the provisions of the Law of 17 November 1964 - Code of Civil Procedure (Journal of Acts of 2020, item 1575 as amended - hereinafter KPC) on proceedings in matters of labour law apply accordingly. Since the court with jurisdiction to hear these cases is the labour court, this will undoubtedly facilitate the redress procedure for the self-employed person, all the more so because, as in the case 
of employees, the burden of proof is being shifted onto the hiring entity. A selfemployed trade union activist merely has to establish before the court the fact of unequal treatment in employment because of the exercise of his trade union function, and then the hiring entity will have to demonstrate that, by differentiating the situation of the employees, he was guided by the objective reasons.

In my view granting self-employed trade union activists the right to equal treatment in employment and to protect them in this respect is a good move. The mere fact of performing a trade union function and representing the rights and interests of workers, in view of the high risk of conflict with the hiring entity, justifies protection against discrimination, irrespective of the type of legal relationship between the activist and that body. This is fully in line with international standards, which are included in ILO Convention No 135. Under Article 1 of that act, all employees' representatives in an enterprise (including trade union activists) should enjoy effective protection against any acts of harm (and therefore also those of a discriminatory nature) taken on the basis of their trade union membership or participation in trade union activities.

\section{RIGHT TO PAID TIME OFF FROM WORK}

Granting self-employed persons the opportunity to act in trade union structures means in consequence that they are entitled - as in the case of guarantees given to regular employees - to paid time off from work, both on an ad hoc basis (for the purpose of carrying out current activities resulting from their trade union function) and permanently. This applies to activities in all trade union organisations - on a sectoral and cross-sectoral level.

As regards ad hoc leaves, in accordance with Article 25(6) of the Trade Union Act, the self-employed person is entitled to take the time off from work necessary to carry out an ad hoc activity resulting from his trade union function outside the establishment if that activity cannot be carried out during his non-working time. That person shall retain the right to remuneration, unless otherwise specified in the special provisions. ${ }^{7}$ The right to such remuneration will therefore depend on the specificities of the legal relationship. If the basis for self-employment is a civil law contract for the provision of services, where the remuneration depends on the number of hours worked, then the payment for the time taken off from work by the self-employed trade union activist will be payable at the rate specified in the contract. If the person's remuneration is specified in the civil law contract on a flatrate basis or depends on the results of the work (e.g. the contract for the specified

${ }^{7}$ The same applies to the right to ad hoc paid leaves which the legislature guarantees to those persons if they have the status of members of the management board of a trade union organisation (Article 31(4) of the Trade Union Act). 
task), then there will be no separate remuneration for the time taken off for the performance of the ad hoc activity. In order to protect the interests of the hiring entity, the legislature pointed out that the contract concluded between that entity and the self-employed, which sets a time limit for the performance of the specified task (e.g. completion of specified task), is not extended by the time taken off from work to perform some ad hoc activity. In addition, the collective agreement may set limits for the time necessary to carry out an ad hoc activity resulting from the trade union function of persons engaged in gainful employment. The very idea of guaranteeing self-employed workers the right to time off from work for the performance of an ad hoc activity resulting from the performance of a trade union function deserves approval. Prima facie, it seems that the legislature has taken into account the specificities of non-employee employment relations here. In my opinion, however, this entitlement goes too far, interfering very significantly with civil contract freedom. Firstly, there is the problem of an acceptable limit on such time off, which has been highly controversial for years in terms of the inconvenience caused to the hiring entity (see Kulig 2015, 9 and the following). I believe that limiting the possibility of setting this limit only to contractual provisions (in Poland the number of collective agreements concluded is rather minor) is insufficient and that the legislature should allow it to be proposed at the level of ordinary agreements concluded between the hiring entity and the trade union party. Secondly, I have doubts as to the right to remuneration for the time taken off from work. Although a derogation from the principle of reciprocity of obligations is permissible on the basis of an employment relationship, which is a manifestation of the protective function of labour law (protection of the weaker party to the employment relationship), the transfer of that mechanism to civil-law relationships, which are not inherently permanent, raises legitimate doubts. In my view, the time off from work necessary for the performance of ad hoc activities resulting from the trade union function in respect of self-employed activists should, in principle, be free of charge and only exceptionally be allowed to be paid, but only for those self-employed persons who are economically dependent on the contracting entity. ${ }^{8}$

On the other hand, covering the self-employed trade union activists with the right to permanent paid time off from work (so-called trade union posts) should not be assessed positively. In accordance with Article 31 of the Trade Union Act, the right to be exempted from the obligation to work for a term of office on the management board of a trade union organisation is also vested in persons other than employees who perform the gainful employment (including

${ }^{8}$ These are self-employed persons whose income is wholly or predominantly derived from the hiring entity where the trade union organisation operates. On the other hand, the draft of 2018 of the Polish Individual Labour Code provided for an hourly criterion of the economic dependence of self-employed persons (provision of services to one entity on average of at least 21 hours per week, for a period of at least 182 days). 
self-employed) designated by that organisation. During the period of such time off, a self-employed trade union activist shall be entitled to the rights or benefits of a person engaged in gainful employment, as well as the right to remuneration or cash benefit, provided that the management of the trade union organisation so requests. Charging employers with the costs related to the provision of rights to trade union activists and the remuneration for longer periods of non-service (creation of artificial trade union posts), when those activists do not provide work but focus solely on the performance of trade union functions, has long raised doubts with regard to employees acting in the structures of a trade union. It is difficult to consider such a solution justified in view of the market economy and equality of the social partners. It is all the more inappropriate in relation to selfemployed trade union activists who are linked to the employing entity with a trade union organization, under a civil law contract that does not guarantee such durability and stabilization of employment conditions as the employment relationship, which usually results in the absence of a strong legal relationship with the workplace (it is clearly visible, for example, in relation to the contract for a specified task). However, if we were to grant self-employed trade union activists the right to permanent paid leave from work for the duration of their term of office on the board of a trade union organisation, it would certainly only be those who provide services to the entity in which such an organisation operates, under conditions of economic dependence. Unfortunately the Polish legislature does not observe such a criterion at all when introducing the right to permanent paid leaves for non-employees.

\section{THE RIGHT TO PROTECTION OF THE DURABILITY OF THE EMPLOYMENT RELATIONSHIP}

The consequence of extending the coalition right to non-employees and enabling self-employed persons to be active in union structures is guaranteeing them the right to increased protection of the durability of civil law contracts constituting the basis of their bond with the entity in which the trade union organization operates. In this respect, the Polish legislature wanted to comply with international standards, under which trade union activists, as representatives of employees in a company, should enjoy effective protection against any acts harmful taken by the hiring entity, including dismissal. Pursuant to Art. 32 of the trade union act, the employing entity may not terminate or dissolve the legal relationship without the consent of the management board of the company trade union organization, cannot terminate or dissolve the legal relationship with the self-employed person who is a member of the trade union organisation concerned, authorised to represent this organization in front of the employer, and may not unilaterally change the working conditions or remuneration to the detriment of 
that person, except in the event of bankruptcy or liquidation of the employer, and also if this is permitted by separate provisions. This protection is granted for a period specified by a resolution of the management board, and after its expiry - additionally for a period corresponding to half of that period, but not longer than one year after its expiry. A similar right is granted by the legislature to a selfemployed person who chooses a trade union function outside the company trade union organization, if he or she benefits from the exemption from the obligation to perform work in the hiring entity. This protection is granted for the period of this exemption and for one year after this period.

What is new is the definition of statutory deadlines (14 or 7 working days) within which a trade union may take a position on whether to agree (or refuse) to terminate a legal relationship with a self-employed trade unionist or unilaterally change its content. The ineffective expiry of those time-limits is tantamount to the consent of the management board of the company trade union organization. That regulation therefore introduces a legal fiction which applies to all trade union activists, regardless of the basis of employment. This is a very important solution that significantly reduces the uncertainty as to the protection of the employment stability of people holding union functions, including the self-employed (see more in Baran 2018b, 23 and the following). As regards non-employees, the existing rules for determining the number of protected trade unionists referring to the parity and progressive method and making this number dependent on the representativeness of the trade union organisation have been maintained (see more in Dral 2018, 254 and the following Cf. also Latos-Miłkowska 2017, 19 and the following). ${ }^{9}$

It can be seen, therefore, that the Polish legislator decided to transfer the employee structure of the special protection of the durability of the employment relationship of union activists to non-employee employment relationships, including self-employed persons operating in the structures of trade unions, both at the workplace and outside the company. This is the first legal regulation (not counting homeworkers) that interferes so much with the principle of freedom of contract applicable under civil law (Art. $353^{1}$ of the Civil Code). There are at least a few arguments against the far-reaching privileges of self-employed trade union activists. Firstly, the legislature extends to those persons the employee rights which for years have aroused justified controversy in the doctrine of the labour law as excessively protecting trade unionists employed on the basis of an employment relationship, exceeding the standards resulting from international regulations (see

${ }^{9}$ Maintaining the progressive method, while expanding the subjective scope of the right of coalition, may in the future lead to an increase in the number of protected trade union activists (as the number of trade union organizations is increasing by members performing paid work on a basis other than an employment relationship). As a consequence, this will place greater burdens on the hiring entity, which may have an impact on the negative perception of trade unions already regarded unfavourably by entrepreneurs in Poland. 
more broadly Kurzynoga 2020, 178 and the following). While it is true that Art. 6 of Recommendation No. 143 of the ILO indicates the need to obtain the consent of the relevant entity to dismiss a trade union activist, but this is to be the consent of an independent entity, and not, as is the case in Polish collective law, a decision of the management board of a trade union. Moreover, the protection of trade union activists in our country is not limited only to cases related to the performance of trade union functions, and the management board of a trade union organization may refuse to consent to a unilateral change or termination of the employment relationship in any case, even if the activist grossly violates his basic obligations resulting from his employment relationship, having no connection with trade union activity (this is often the case in real life, e.g. drinking alcohol in the workplace). In such a situation, the hiring entity may claim its rights only in court by using the construction of an abuse of rights which is used by the trade union activist in a manner contrary to the socio-economic purpose or principles of social coexistence (Article 8 of the Labour Code). ${ }^{10}$ Secondly, the application to self-employed trade union activists of the mechanism of obtaining the consent of the trade union management board to terminate a civil law contract does not take into account at all the specificities of the functioning of self-employed persons, who most often do not have such a strong legal bond with the hiring entity as employees. This is too far-reaching interference in the rights and obligations of parties to contracts governed by dispositive standards of the Civil Code. In my opinion, the Polish legislator cannot restrict the employing entity's right to terminate a civil law contract with a self-employed trade union activist in the event of a gross violation of its provisions not related to his function in trade union structures. This is completely contrary to the nature of civil law contracts. This is too far-reaching interference in the rights and obligations of parties to contracts governed by dispositive standards of the Civil Code. In my opinion, the Polish legislator cannot restrict the employing entity's right to terminate a civil law contract with a self-employed trade union activist in the event of a gross violation of its provisions not related to his function in trade union structures. This is completely contrary to the nature of civil law contracts. A sufficient mechanism for the protection of such a trade union activist, taking full account of the specific characteristics of self-employment, would be to guarantee him high compensation in the event of termination of his civil law contract in connection with his duties in the structures of a trade union. Thirdly, even if the Polish legislator decided to introduce a requirement for the consent of the management board of a trade union organization to terminate a civil law contract with a self-employed trade union activist, this mechanism should not apply to all trade unionists - non-employees, but only to those who are economically dependent on the hiring entity.

${ }^{10}$ While Article 8 of the Labour Code will apply to trade union activists employed on the basis of an employment relationship, Article 5 of the Civil Code applies to self-employed trade unionists. 
On the other hand, the limited scope of claims which a self-employed trade union activist may assert from the hiring entity in the event of termination of a civil law contract without the prior consent of the management board of the trade union organisation must be assessed positively. Here, the legislature did not decide on the right of workers to restitution of the employment relationship (this is the effect of the court's recognition of the claim for reinstatement). This would not only be contrary to the nature of civil law contracts, but also, in the conditions of a market economy, it would have a rather façade character (Baran 2018a, 9). Pursuant to Article $32\left(1^{3}\right)$ of the Trade Union Act, in the event of a breach of the protection of trade union activists, a self-employed person is entitled, irrespective of the amount of damage suffered, to compensation in the amount equal to the 6-month remuneration to which that person was entitled in the last period of employment, and if the remuneration of that person is not paid monthly - in the amount equal to 6 times the average monthly salary in the national economy in the previous year. ${ }^{11}$ When determining the amount of this compensation, the average monthly remuneration for the period of 6 months preceding the date of termination, dissolution or unilateral change of the legal relationship is taken into account, and if the self-employed person has been working for a period shorter than 6 months - the average monthly remuneration for the entire period. Thus, the compensation for the self-employed trade union activist has not only a compensatory nature, but is also a kind of repression against an entity that has violated the protection of the durability of the employment of trade union activists. Its amount is minimal and may in a specific case exceed the amount of damage suffered by the dismissed trade union activist (Baran 2018b, 25). The legislature has therefore taken into account, unlike in the regulations analysed so far, the specificities of self-employment provided in the context of a sole proprietorship, which deserves approval. In addition, a self-employed trade union activist may claim, under the general rules of civil law, compensation or redress exceeding the amount of the damages. It seems that in this case both the tort and contractual liability regime is at stake (Grzebyk, Pisarczyk 2019, 92).

Termination by the hiring entity a civil law contract with a self-employed trade union activist or unilaterally changing its provisions in violation of Article 32 of the Trade Union Act does not make the legal act of this entity absolutely invalid. By adopting the mechanism known under the employment relationship, the legislator recognizes the effectiveness of this activity. In such a case, however, this activity is defective, and the self-employed person may apply to the court for the payment of compensation in the amount equal to the 6-month remuneration. A significant drawback of the analyzed regulation is the lack of a provision

${ }^{11}$ This is the minimum amount of compensation guaranteed by the legislature, which may be increased by means of a collective agreement or other agreement concluded between the hiring entity and the trade unions. 
which, in that regard, would expressis verbis give self-employed workers acting as trade union activists the right to assert such claim in proceedings before a labour court. This would guarantee them - as in the case of employees - the possibility of enjoying a privileged position in labour law proceedings and faster and more effective enforcement of claims. De lege lata, it is impossible to agree with the position sometimes presented in the doctrine of labour law (Baran 2018b, 26; Kurzynoga 2020, 182) that we are dealing here with the cognition of labour courts, and these cases are matters from other legal relations, to which, under separate provisions, the provisions of the labour law should be applied (Article $476 \S 1$ point 2 of the Code of Civil Procedure). It is true that labour courts are the best prepared substantively to resolve trade union cases, however, a literal interpretation of the trade union act excludes their jurisdiction in this area, making them competent to consider claims under Article 32 civil courts (similarly Grzebyk, Pisarczyk 2019, 92). If the legislator wanted to provide for the cognition of labour courts in these matters, it would directly regulate this issue, as it will do with the claims of self-employed trade union activists for violation of the prohibition of unequal treatment in employment due to the performance of a trade union function. Pursuant to Article $3 \mathrm{sec} .3$ of the Trade Union Act, the provisions of the Civil Procedure Code on proceedings in matters relating to labour law shall apply accordingly to proceedings in discriminatory cases against persons who perform paid work other than employees. The competent court to hear these cases is the competent labour court. A similar regulation should be included in Article 32 of the Trade Union Act.

\section{CONCLUSIONS}

It should be assessed positively that the Polish legislator, by extending the right of coalition to self-employed persons who perform gainful employment as sole traders, at the same time granted them certain rights and privileges in the field of their activity in trade union structures. The Trade Union Act extended protection to self-employed union activists, which until 2019 was granted exclusively to employees. Pursuant to the amendment of July 5, 2018, these persons were granted - based on international standards - the right to non-discrimination on the basis of performing a trade union function, the right to paid leaves from work, both permanent and temporary, for the purpose of performing current activities resulting from the performed trade union function, as well as protection of the durability of civil law contracts constituting the legal basis for the services provided.

An analysis of the Polish trade union law leads to the conclusion that the scope of privileges granted to self-employed trade unionists practically does not differ much from the privileges granted to trade union activists having the 
employee status. Such a method of regulation should be clearly considered defective. The legislator does not sufficiently notice the separateness resulting from civil law contracts, which constitute the basis for the performance of work by the self-employed. In my opinion, the scope of rights guaranteed de lege lata to self-employed trade union activists constitutes an excessive and unjustified interference with the fundamental principle of freedom of contract on the basis of civil law employment relations. This regulation does not take into account the specificity of self-employed persons, who most often do not have such strong legal relationship with the hiring entity as employees. While the far-reaching protection of self-employed trade unions in terms of equal treatment due to the performance of trade union functions (here differences would be difficult to accept) should be fully supported, the right to paid leaves from work (permanent and temporary) and the absolute requirement for the consent of the trade union management board to terminate the civil law contract are completely unconvincing. These are mechanisms that overburden the entities where the trade unions are formed. They generate additional unjustified costs and make it difficult to operate in a market economy.

The disadvantage of the regulation analyzed is also that Polish collective labour law does not in any way differentiate the scope of the rights and privileges guaranteed to self-employed trade unionists, ensuring the same level of protection for all. In that area, it appears that the legislature de lege ferenda should differentiate the scope of that protection by referring to the criterion of economic dependence on the hiring entity for which the services are provided. This means that the widest range of powers and privileges (closest to that of employees) should apply to those self-employed trade union activists whose income is wholly or predominantly derived from the hiring entity where the trade union organisation operates. Such a criterion for the application of powers (including of a collective nature) to the self-employed is found in the legislation of certain European countries. For example, the Spanish legislature, in a special law on the status of self-employed persons, took the view that the economically dependent self-employed worker is a self-employed person who earns at least $75 \%$ of his income from one contractor (Article 11 of the law of 11 July 2007 concerning the status of independent work Ley 20/2007, de 11 de julio, del Estatuto del trabajo autónomo, BOE núm. 166, de 12/07/2007). A similar situation can be observed in German law, where the above mentioned income threshold is 50\% (see opinion of the European Economic and Social Committee on New trends in self-employed work: the specific case of economically dependent self-employed work of 29 April 2010, SOC/344- CESE $639 / 2010,7-8)$. The Italian legislature, on the other hand, does not use the income threshold when it comes to demonstrating economic dependence, but rather the so-called 'criterion of permanent cooperation'. On the other hand, the draft of the Polish Labour Code of 2008 defined economic dependence as a situation in which a person providing services on the basis of a contract other than an employment 
contract performs in person for one hiring entity work of a continuous or recurring nature for the remuneration exceeding half of the minimum wage, and as work for the hiring entity, from whom the employed person receives a greater proportion of the salary if it exceeds half of the minimum wage (Article 462). On the other hand, the 2018 draft of the Individual Labour Code provided for the hourly criterion of economic dependence of self-employed persons (Article $177 \S 1$ of this draft). Since in the literature on the subject the criterion of economic dependence is sometimes questioned as being difficult to verify and establish in practice, differentiating the scope of rights of self-employed trade union activists, one can also refer to the objective criterion of working for a period of at least 6 months for the entity covered by the operation of a given trade union organization.

\section{BIBLIOGRAPHY}

Baran, Krzysztof Wojciech. 2018a. "O ochronie trwałości stosunku zatrudnienia związkowców na poziomie zakładowym - uwagi de lege ferenda". Monitor Prawa Pracy 4: 6-10.

Baran, Krzysztof Wojciech. 2018b. "Refleksje o ochronie stosunku zatrudnienia działaczy związkowych na poziomie zakładowym po nowelizacji ustawy związkowej z 5 lipca 2018 r.”. Praca i Zabezpieczenie Społeczne 10: 21-26.

Dral, Antoni. 1997/1998. "Konfliktogenność funkcji społecznych i obywatelskich jako przesłanka szczególnej ochrony trwałości stosunku pracy". In Studia z Zakresu Prawa Pracy i Polityki Społecznej. Edited by Andrzej Świątkowski. 285-302. Kraków: Uniwersytet Jagielloński.

Dral, Antoni. 2018. "Ochrona trwałości stosunku pracy działaczy związkowych w świetle noweli ustawy o związkach zawodowych”. Studia z Zakresu Prawa Pracy i Polityki Społecznej 25(3): 243-269.

Duraj, Tomasz. 2009. "Praca na własny rachunek a prawo pracy". Praca i Zabezpieczenie Społeczne 11: 24-33.

Duraj, Tomasz. 2018. "Funkcja ochronna prawa pracy a praca na własny rachunek". In Ochronna funkcja prawa pracy. Wyzwania współczesnego rynku pracy. Edited by Anna Napiórkowska, Beata Rutkowska, Mikołaj Rylski. 37-56. Toruń: TNOiK.

Duraj, Tomasz. 2019. "Uprawnienia związane z rodzicielstwem osób samozatrudnionych - uwagi de lege lata i de lege ferenda". Studia z Zakresu Prawa Pracy i Polityki Społecznej 26(4): 341-366.

Duraj, Tomasz. 2020. "Prawo koalicji osób pracujących zarobkowo na własny rachunek po nowelizacji prawa związkowego - szanse i zagrożenia”. Studia z Zakresu Prawa Pracy i Polityki Spolecznej 27(2): 67-77.

Grzebyk, Piotr. Łukasz Pisarczyk. 2019. "Krajobraz po reformie. Zbiorowa reprezentacja praw i interesów zatrudnionych niebędących pracownikami”. Praca i Zabezpieczenie Społeczne 1: 81-98.

Kulig, Karol. 2015. "Doraźne czynności związkowe. Prawo podmiotowe pracownika czy prawo organizacji związkowej”. Praca i Zabezpieczenie Społeczne 8: 9-15.

Kurzynoga, Małgorzata. 2019. “Ochrona przedstawicieli pracowników i przysługujące im ułatwienia". In System Prawa Pracy, Międzynarodowe publiczne prawo pracy. Standardy globalne. Tom 9. Edited by Krzysztof Wojciech Baran. 1082-1115. Warszawa: Wolters Kluwer Polska. 
Kurzynoga, Małgorzata. 2020. "Ochrona stosunku zatrudnienia działaczy związkowych po nowelizacji ustawy związkowej z dnia 5 lipca 2018 r. w świetle standardów międzynarodowego prawa pracy”. Studia z Zakresu Prawa Pracy i Polityki Społecznej 27(3): 175-185.

Latos-Miłkowska, Monika. 2017. "Ustalanie zakresu podmiotowego ochrony udzielanej działaczom związkowym”. Praca i Zabezpieczenie Spoteczne 9: 19-23.

Podgórska-Rakiel, Ewa. 2013. "Rekomendacje MOP dotyczące wolności koalicji związkowej i ochrony działaczy". Monitor Prawa Pracy 2: 68-73.

Podgórska-Rakiel, Ewa. 2014. "Konieczność nowelizacji prawa polskiego w kwestii wolności związkowych z perspektywy Międzynarodowej Organizacji Pracy". Monitor Prawa Pracy 10: $510-514$.

Salwa, Zbigniew. 1997. "Szczególna ochrona stosunku pracy działaczy związkowych". Praca i Zabezpieczenie Spoleczne 5: 12-17.

Sanetra, Walerian. 1993. "Dylematy ochrony działaczy związkowych przed zwolnieniem z pracy". Praca i Zabezpieczenie Spoleczne 3: 21-34.

Sobczyk, Arkadiusz. 2017. "Zakładowy i niezakładowy związek zawodowy a problem demokracji zakładowej”. In Demokracja w zakładzie pracy. Zagadnienia prawne. Edited by Zbigniew Hajn, Małgorzata Kurzynoga. 167-180. Warszawa: Wolters Kluwer.

Stelina, Jakub. 2018. "Zbiorowe prawo zatrudnienia - podstawowe założenia teoretyczne". In Zbiorowe prawo zatrudnienia. Edited by Jakub Stelina, Jakub Szmit. 13-32. Warszawa: Wolters Kluwer Polska. 